Keywords: gadolinium, oxalate, solubility, canyon

Retention: Permanent

\title{
Gadolinium Oxalate Solubility Measurements in Nitric Acid Solutions
}

R. A. Pierce

March 2012

Savannah River National Laboratory Savannah River Nuclear Solutions Aiken, SC 29808

Prepared for the U.S. Department of Energy under

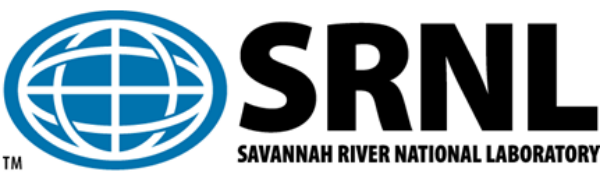
contract number DE-AC09-08SR22470. 
SRNL-STI-2012-00098

Revision 1

\section{DISCLAIMER}

This work was prepared under an agreement with and funded by the U.S. Government. Neither the U.S. Government or its employees, nor any of its contractors, subcontractors or their employees, makes any express or implied:

1. warranty or assumes any legal liability for the accuracy, completeness, or for the use or results of such use of any information, product, or process disclosed; or

2. representation that such use or results of such use would not infringe privately owned rights; or

3. endorsement or recommendation of any specifically identified commercial product, process, or service.

Any views and opinions of authors expressed in this work do not necessarily state or reflect those of the United States Government, or its contractors, or subcontractors.

\section{Printed in the United States of America \\ Prepared for \\ U.S. Department of Energy}




\section{REVIEWS AND APPROVALS}

AUTHORS:

R.A. Pierce, Separations and Actinide Science Programs

Date

TECHNICAL REVIEW:

N. J. Bridges, Technical Reviewer

Date

Separations and Actinide Science Programs

S.L. Garrison, Technical Reviewer

Date

Outside Facilities and Technical Support Engineering

APPROVAL:

S.D. Fink, Manager

Date

Separations and Actinide Science Programs

S.L. Marra, Manager

Date

Environmental \& Chemical Process Technology Research Programs

W.G. Dyer, Manager

Date

Outside Facilities and Technical Support Engineering 


\begin{tabular}{|c|c|c|}
\hline \multicolumn{3}{|c|}{ LIST OF REVISIONS } \\
\hline $\begin{array}{l}\text { Revision } \\
\text { Number }\end{array}$ & Summary of Changes & Date \\
\hline 1 & $\begin{array}{l}\text { Added new data for gadolinium oxalate solubility at } 10{ }^{\circ} \mathrm{C} \text {. } \\
\text { Added new data for gadolinium nitrate solubility at } 20-22{ }^{\circ} \text {. } \\
\text { Updated the values reported for gadolinium oxalate solubility } \\
\text { at } 25^{\circ} \mathrm{C} \text { to more accurately interpret the data in Figure } 4-2 \text {. }\end{array}$ & $3 / \mathbf{8} / \mathbf{1 2}$ \\
\hline & & \\
\hline & & \\
\hline & & \\
\hline & & \\
\hline & & \\
\hline & & \\
\hline & & \\
\hline & & \\
\hline & & \\
\hline & & \\
\hline & & \\
\hline & & \\
\hline & & \\
\hline & & \\
\hline & & \\
\hline & & \\
\hline & & \\
\hline & & \\
\hline & & \\
\hline & & \\
\hline
\end{tabular}




\section{EXECUTIVE SUMMARY}

HB-Line will begin processing Pu solutions during FY2012 that will involve the recovery of $\mathrm{Pu}$ using oxalate precipitation and filtration. After the precipitation and filtration processes, the filtrate solution will be transferred from HB-Line to H-Canyon. The presence of excess oxalate and unfiltered Pu oxalate solids in these solutions create a criticality safety issue if they are sent to $\mathrm{H}$-Canyon without controls in $\mathrm{H}$-Canyon. One approach involves $\mathrm{H}$-Canyon receiving the filtrate solution into a tank that is poisoned with soluble gadolinium (Gd). Decomposition of the oxalate will occur within a subsequent $\mathrm{H}$-Canyon vessel.

The receipt of excess oxalate into the H-Canyon receipt tanks has the potential to precipitate a portion of the Gd poison in the receipt tanks. Because the amount of Gd in solution determines the maximum amount of Pu solids that $\mathrm{H}$-Canyon can receive, $\mathrm{H}$-Canyon Engineering requested that SRNL determine the solubility of $\mathrm{Gd}$ in aqueous solutions of 4-10 $\mathrm{M}$ nitric acid $\left(\mathrm{HNO}_{3}\right)$, 4-12 g/L Gd, and 0.15-0.25 M oxalic acid $\left(\mathrm{H}_{2} \mathrm{C}_{2} \mathrm{O}_{4}\right)$ at $25{ }^{\circ} \mathrm{C}$. The target soluble $\mathrm{Gd}$ concentration is $6 \mathrm{~g} / \mathrm{L}$. The data indicate that the target can be achieved above $6 \mathrm{M} \mathrm{HNO}_{3}$ and below $0.25 \mathrm{M} \mathrm{H}_{2} \mathrm{C}_{2} \mathrm{O}_{4}$.

At $25{ }^{\circ} \mathrm{C}$, for $6 \mathrm{M} \mathrm{HNO}_{3}, 11 \mathrm{~g} / \mathrm{L}$ and $7 \mathrm{~g} / \mathrm{L} \mathrm{Gd}$ are soluble in $0.15 \mathrm{M}$ and $0.25 \mathrm{M} \mathrm{H}_{2} \mathrm{C}_{2} \mathrm{O}_{4}$, respectively. In $4 \mathrm{M} \mathrm{HNO}_{3}$, the Gd solubility drops significantly to $2.5 \mathrm{~g} / \mathrm{L}$ and $0.8 \mathrm{~g} / \mathrm{L}$ in $0.15 \mathrm{M}$ and $0.25 \mathrm{M} \mathrm{H}_{2} \mathrm{C}_{2} \mathrm{O}_{4}$, respectively. The solubility of Gd at 8-10 $\mathrm{M} \mathrm{HNO}_{3}$ exceeds the solubility at $6 \mathrm{M} \mathrm{HNO}_{3}$. The data for $4 \mathrm{M} \mathrm{HNO}_{3}$ showed good agreement with data in the literature. To achieve a target of $6 \mathrm{~g} / \mathrm{L}$ soluble $\mathrm{Gd}$ in solution in the presence of $0.15-0.25 \mathrm{M}$ oxalate, the $\mathrm{HNO}_{3}$ concentration must be maintained at or above $6 \mathrm{M} \mathrm{HNO}_{3}$.

The solubility of $\mathrm{Gd}$ in $4 \mathrm{M} \mathrm{HNO}_{3}$ with $0.15 \mathrm{M}$ oxalate at $10^{\circ} \mathrm{C}$ is about $1.5 \mathrm{~g} / \mathrm{L}$. For $6 \mathrm{M} \mathrm{HNO}_{3}$ with $0.15 \mathrm{M}$ oxalate, the solubility of $\mathrm{Gd}$ at $10^{\circ} \mathrm{C}$ is about $10 \mathrm{~g} / \mathrm{L}$.

Gadolinium nitrate is very soluble in $\mathrm{HNO}_{3}$. The solubility of $\mathrm{Gd}$ is linear as a function of $\mathrm{HNO}_{3}$ from $343 \mathrm{~g} / \mathrm{L} \mathrm{Gd}$ in $2.88 \mathrm{M} \mathrm{HNO}_{3}$ to $149 \mathrm{~g} / \mathrm{L}$ in $8.16 \mathrm{M} \mathrm{HNO}_{3}$. Below $2.88 \mathrm{M} \mathrm{HNO}_{3}$, the solubility of $\mathrm{Gd}$ approaches a limit of about $360 \mathrm{~g} / \mathrm{L}$. However, there are no data available below $1.40 \mathrm{M} \mathrm{HNO}_{3}$, which has a Gd solubility of $353 \mathrm{~g} / \mathrm{L}$. 


\section{TABLE OF CONTENTS}

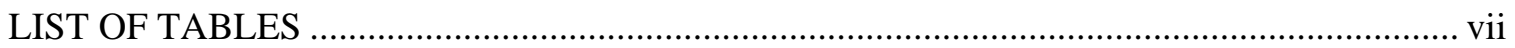

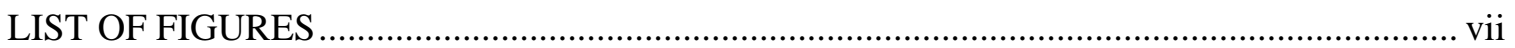

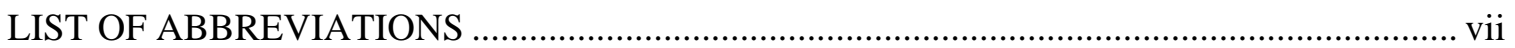

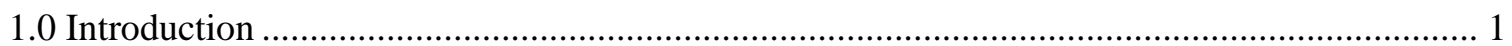

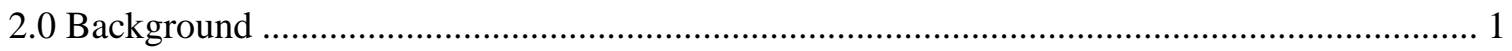

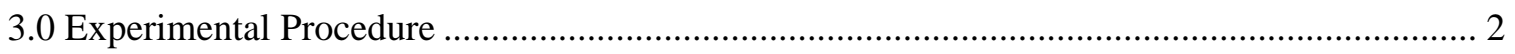

3.1 Gadolinium Nitrate - Nitric Acid - Oxalic Acid .................................................................. 2

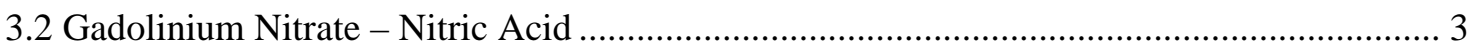

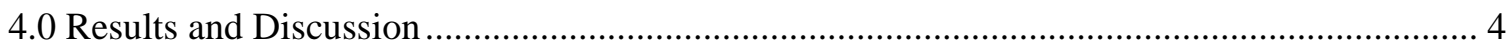

4.1 Gadolinium Nitrate - Nitric Acid - Oxalic Acid .............................................................. 4

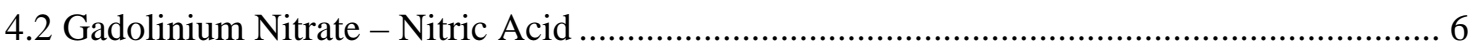

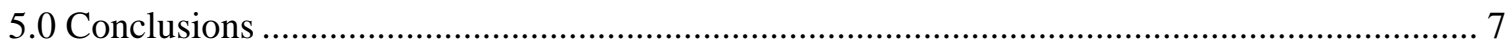

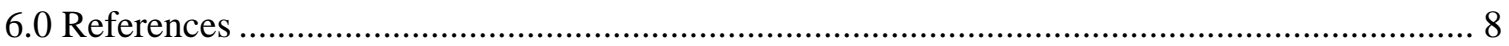




\section{LIST OF TABLES}

Table 3-1. Test Matrix Final Target Concentrations and Preparation Masses ............................... 2

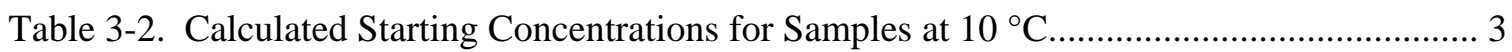

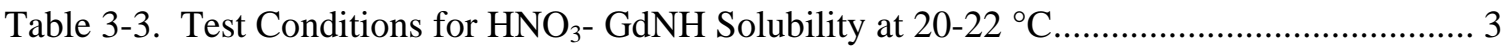

Table 4-1. Soluble Gadolinium and Oxalate Concentrations in 4-10 $\mathrm{M} \mathrm{HNO}_{3}$ at $25^{\circ} \mathrm{C} \ldots \ldots \ldots \ldots . . . . .4$

Table 4-2. Soluble Gadolinium and Oxalate Concentrations in 4-8 $\mathrm{M} \mathrm{HNO}_{3}$ at $10{ }^{\circ} \mathrm{C} \ldots \ldots \ldots \ldots . . . . . . .5$

Table 4-3. Calculated Solution Concentrations after Addition of GdNH .................................... 6

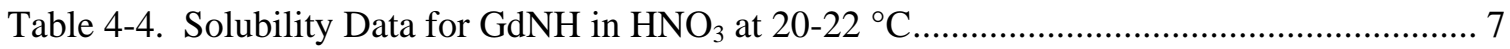

\section{LIST OF FIGURES}

Figure 2-1. Gadolinium Oxalate Solubility in Nitric Acid ............................................................ 1

Figure 4-1. Gadolinium Solubility as Functions of $\mathrm{HNO}_{3}$ and Oxalate at $25{ }^{\circ} \mathrm{C}$.......................... 5

Figure 4-2. Gadolinium Solubility as Functions of $\mathrm{HNO}_{3}$ and Oxalate at 10 and $25^{\circ} \mathrm{C} \ldots \ldots \ldots \ldots . . . . .6$

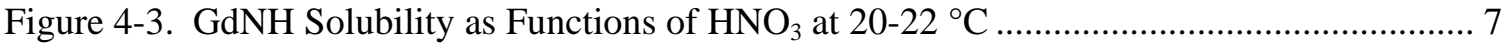

\section{LIST OF ABBREVIATIONS}

$\begin{array}{ll}\text { AD } & \text { Analytical Development } \\ \text { DI } & \text { de-ionized } \\ \text { GdNH } & \text { gadolinium nitrate hexahydrate } \\ \text { IC } & \text { ion chromatography } \\ \text { ICPES } & \text { inductively coupled plasma emission spectroscopy } \\ \text { NP }>4 & \text { no precipitate after } 4 \text { days } \\ \text { NP }>11 & \text { no precipitate after 11 days } \\ \text { NM } & \text { not measured } \\ \text { SRNL } & \text { Savannah River National Laboratory }\end{array}$




\subsection{Introduction}

HB-Line will begin processing Pu solutions during FY2012 that will involve the recovery of Pu using oxalate precipitation and filtration. After the precipitation and filtration processes, the presence of excess oxalate and unfiltered $\mathrm{Pu}$ oxalate solids pose a criticality safety issue downstream of HB-Line. In previous campaigns, HB-Line performed an oxalate decomposition (or oxalate "kill”) step to prevent the transfer of excess oxalate and $\mathrm{Pu}$ oxalate solids to the nongeometrically favorable tanks within H-Canyon. The current flowsheet has H-Canyon receiving the filtrate solution with possible Pu solids into a tank that is poisoned with Gd in solution; decomposition of the oxalate will occur within a subsequent $\mathrm{H}$-Canyon vessel.

The receipt of excess oxalate into the H-Canyon receipt tank has the potential to precipitate a portion of the Gd poison in the receipt tanks. ${ }^{[1]}$ The amount of Gd in solution determines the maximum amount of $\mathrm{Pu}$ solids that $\mathrm{H}$-Canyon can receive. The current $\mathrm{H}$-Canyon target is a minimum of $6 \mathrm{~g} / \mathrm{L} \mathrm{Gd}$ in solution at nitric acid $\left(\mathrm{HNO}_{3}\right)$ concentrations of 6-10 M. H-Canyon Engineering requested that SRNL determine the solubility of $\mathrm{Gd}$ in aqueous solutions of $\mathrm{HNO}_{3}$ and oxalic acid $\left(\mathrm{H}_{2} \mathrm{C}_{2} \mathrm{O}_{4}\right)$ at $25{ }^{\circ} \mathrm{C} .{ }^{[2]}$ A subsequent request was made to measure Gd oxalate solubility at $10{ }^{\circ} \mathrm{C}$ and $\mathrm{Gd}$ nitrate solubility at ambient temperature $\left(\sim 20^{\circ} \mathrm{C}\right) .{ }^{[3]}$

\subsection{Background}

The precipitation of lanthanides, such as Gd, has been studied at SRNL ${ }^{[4]}$ and solubility data are available in the literature. ${ }^{[1,5]}$ The research by Sarver and Brinton ${ }^{[1]}$ is of particular interest because it was conducted in 2-4 $\mathrm{M} \mathrm{HNO}_{3}$ and 0-0.25 $\mathrm{M} \mathrm{H}_{2} \mathrm{C}_{2} \mathrm{O}_{4}$. Figure 2-1 contains the data pertinent to this study. The SRNL data were collected at 4-10 $\mathrm{M} \mathrm{HNO}_{3}$ and 0.15-0.25 $\mathrm{M} \mathrm{H}_{2} \mathrm{C}_{2} \mathrm{O}_{4}$ to address the operating range for $\mathrm{H}$-Canyon. Although the data at $4 \mathrm{M} \mathrm{HNO}_{3}$ and $0.25 \mathrm{M}$ $\mathrm{H}_{2} \mathrm{C}_{2} \mathrm{O}_{4}$ do not meet the $\mathrm{H}$-Canyon objectives, the trends as functions of $\mathrm{HNO}_{3}$ and $\mathrm{H}_{2} \mathrm{C}_{2} \mathrm{O}_{4}$ concentrations indicate that adequate solubility of $\mathrm{Gd}$ may occur at higher $\mathrm{HNO}_{3}$ concentrations and lower $\mathrm{H}_{2} \mathrm{C}_{2} \mathrm{O}_{4}$ concentrations.

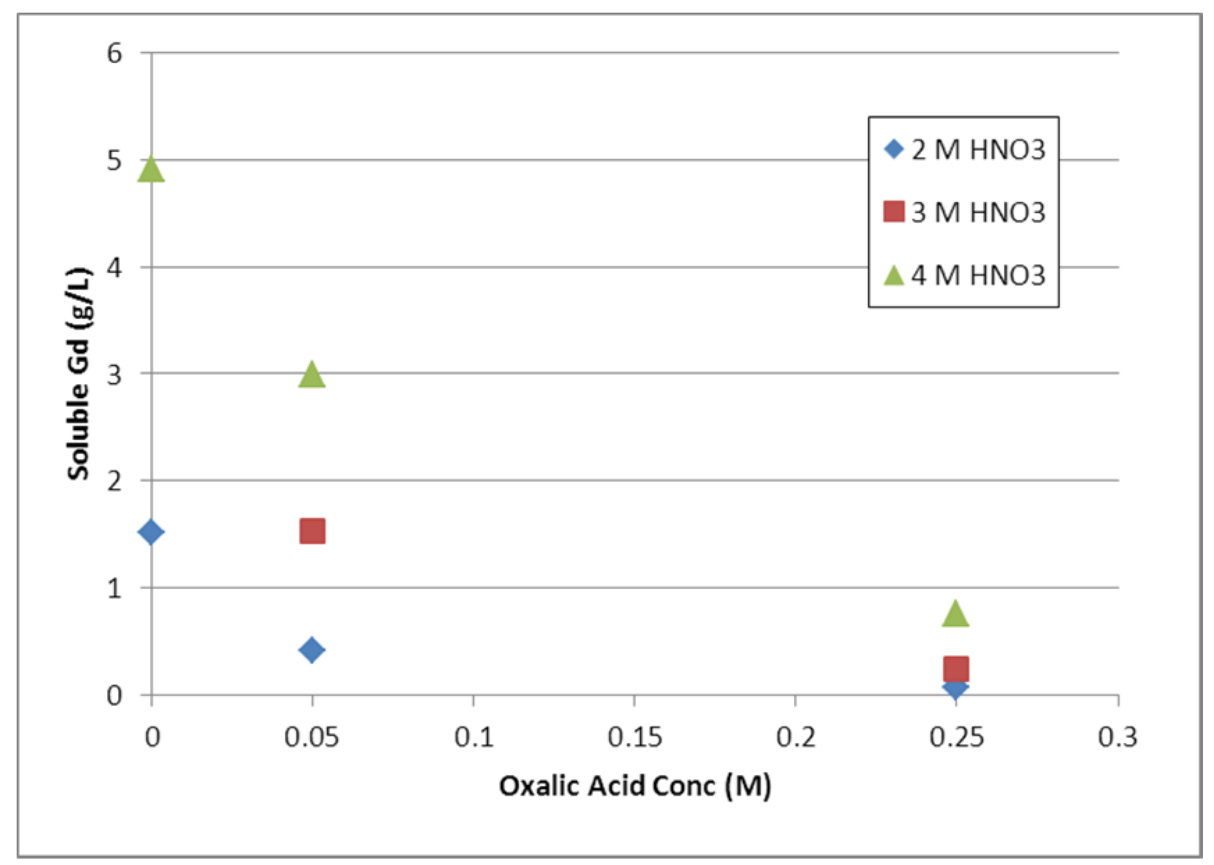

Figure 2-1. Gadolinium Oxalate Solubility in Nitric Acid ${ }^{[1]}$ 


\subsection{Experimental Procedure}

\subsection{Gadolinium Nitrate - Nitric Acid - Oxalic Acid}

A solubility test matrix was established that varied the $\mathrm{HNO}_{3}(4-10 \mathrm{M}), \mathrm{H}_{2} \mathrm{C}_{2} \mathrm{O}_{4}(0.15-0.25 \mathrm{M})$, and Gd (4-12 g/L) concentrations. The target concentrations are listed in Table 3-1. Samples were prepared by adding the chemicals of Table 3-1 into 60-mL polyethylene bottles and diluting with de-ionized (DI) water to $25 \mathrm{~mL}$. The $1 \mathrm{M} \mathrm{H}_{2} \mathrm{C}_{2} \mathrm{O}_{4}$ was prepared by combining $55.046 \mathrm{~g}$ of DI water with $7.4427 \mathrm{~g}$ of $\mathrm{H}_{2} \mathrm{C}_{2} \mathrm{O}_{4}-2 \mathrm{H}_{2} \mathrm{O}$ in a polyethylene bottle, adding a Teflon ${ }^{\mathrm{TM}}$-coated stir bar, and stirring at ambient temperature for $24 \mathrm{~h}$ (the final volume was $59 \mathrm{~mL}$ ).

The bottles were capped and placed into a controlled-temperature water bath with a shaker table. The samples were maintained at $25 \pm 1^{\circ} \mathrm{C}$ for the duration of the test and shaken periodically. The samples were regularly inspected for the formation of a precipitate.

After $30 \mathrm{~h}$ at temperature, only Sample 2 formed a precipitate. Consequently, $0.287 \mathrm{~g}$ of gadolinium nitrate hexahydrate (the equivalent of $4 \mathrm{~g} / \mathrm{L} \mathrm{Gd}$ ) were added to the remaining nine samples. Therefore, Samples 1, 3, and 4 contained $\sim 0.574 \mathrm{~g}$ of $\mathrm{Gd}\left(\mathrm{NO}_{3}\right)_{3}-6 \mathrm{H}_{2} \mathrm{O}[\mathrm{GdNH}](\sim 8 \mathrm{~g} / \mathrm{L}$ Gd), and Samples 5-10 contained $\sim 0.861 \mathrm{~g}$ of GdNH ( 12 g/L Gd). The final GdNH additions and Gd concentrations are shown in Table 3-1.

Table 3-1. Test Matrix Final Target Concentrations and Preparation Masses

\begin{tabular}{|c|c|c|c|c|c|c|}
\hline & \multicolumn{3}{|c|}{ Target Concentrations } & \multicolumn{3}{|c|}{ Added and Diluted to $25 \mathrm{~mL}$} \\
\hline Sample & $\begin{array}{c}\mathrm{HNO}_{3} \\
(\mathrm{M})\end{array}$ & $\begin{array}{c}\mathrm{H}_{2} \mathrm{C}_{2} \mathrm{O}_{4} \\
(\mathrm{M})\end{array}$ & $\begin{array}{c}\text { Gd } \\
(\mathrm{g} / \mathrm{L})\end{array}$ & $\begin{array}{c}15.7 \mathrm{M} \mathrm{HNO}_{3} \\
(\mathrm{~mL})\end{array}$ & $\begin{array}{c}1 \mathrm{M} \mathrm{H}_{2} \mathrm{C}_{2} \mathrm{O}_{4} \\
(\mathrm{~mL})\end{array}$ & $\begin{array}{c}\text { GdNH* } \\
\text { (g) }\end{array}$ \\
\hline 1 & 4 & 0.15 & 8 & 6.37 & 3.75 & $0.574^{\#}$ \\
\hline 2 & 4 & 0.25 & 4 & 6.37 & 6.25 & 0.287 \\
\hline 3 & 6 & 0.15 & 8 & 9.55 & 3.75 & $0.574^{\#}$ \\
\hline 4 & 6 & 0.25 & 8 & 9.55 & 6.25 & $0.574^{\#}$ \\
\hline 5 & 6 & 0.15 & 12 & 9.55 & 3.75 & $0.861^{\#}$ \\
\hline 6 & 6 & 0.25 & 12 & 9.55 & 6.25 & $0.861^{\#}$ \\
\hline 7 & 8 & 0.15 & 12 & 12.74 & 3.75 & $0.861^{\#}$ \\
\hline 8 & 8 & 0.25 & 12 & 12.74 & 6.25 & $0.861^{\#}$ \\
\hline 9 & 10 & 0.15 & 12 & 15.92 & 3.75 & $0.861^{\#}$ \\
\hline 10 & 10 & 0.25 & 12 & 15.92 & 6.25 & $0.861^{\#}$ \\
\hline
\end{tabular}

After 5 days, liquid subsamples were submitted to Analytical Development (AD) from Samples 1, 2, 4, 6, and 8 for analysis by inductively coupled plasma emission spectroscopy (ICPES) and ion chromatography (IC). After 7 days, a few crystals of $\mathrm{H}_{2} \mathrm{C}_{2} \mathrm{O}_{4}-2 \mathrm{H}_{2} \mathrm{O}$ were added to Samples 3, 5, 7 , and 9 to facilitate precipitation. After 11 days, liquid subsamples were withdrawn from Samples 3, 5, 7, 9, and 10 for analysis by ICPES and IC. The samples for each analysis contained $\sim 1.8 \mathrm{~mL}$. 
Samples 1, 3, 5, and 7 were placed into a water bath at $10{ }^{\circ} \mathrm{C}$ for 4 days. After four days, liquid subsamples were withdrawn for analyses by ICPES and IC. Accounting for the removal of $3.6 \mathrm{~mL}$ of subsample of known concentration (Table 4-1) from Samples 1, 3, 5, and 7, the starting concentrations of those four samples were calculated (Table 3-2).

Table 3-2. Calculated Starting Concentrations for Samples at $10{ }^{\circ} \mathrm{C}$

\begin{tabular}{|c|c|c|c|}
\cline { 2 - 4 } \multicolumn{1}{c|}{} & \multicolumn{3}{|c|}{ Starting Concentrations } \\
\hline Sample & $\begin{array}{c}\mathrm{HNO}_{3} \\
(\mathrm{M})\end{array}$ & $\begin{array}{c}\mathrm{H}_{2} \mathrm{C}_{2} \mathrm{O}_{4} \\
(\mathrm{M})\end{array}$ & $\begin{array}{c}\mathrm{Gd} \\
(\mathrm{g} / \mathrm{L})\end{array}$ \\
\hline 1 & 4 & 0.157 & 8.76 \\
\hline 3 & 6 & 0.150 & 8.00 \\
\hline 5 & 6 & 0.151 & 12.1 \\
\hline 7 & 8 & 0.150 & 12.0 \\
\hline
\end{tabular}

\subsection{Gadolinium Nitrate - Nitric Acid}

Four 20-mL solutions were prepared in 30-mL polyethylene bottles using calibrated pipettes $4 \mathrm{M} \mathrm{HNO}_{3}$, $6 \mathrm{M} \mathrm{HNO}_{3}, 8 \mathrm{M} \mathrm{HNO}_{3}$, and $10 \mathrm{M} \mathrm{HNO}_{3}$. At ambient temperature $\left(20-22{ }^{\circ} \mathrm{C}\right)$, incremental additions of $\mathrm{Gd}\left(\mathrm{NO}_{3}\right)_{3}-6 \mathrm{H}_{2} \mathrm{O}$ were made to the bottles. The bottles were capped and shook for at least $30 \mathrm{~min}$ or until the $\mathrm{Gd}\left(\mathrm{NO}_{3}\right)_{3}-6 \mathrm{H}_{2} \mathrm{O}$ dissolved. Additions of $\mathrm{Gd}\left(\mathrm{NO}_{3}\right)_{3}-6 \mathrm{H}_{2} \mathrm{O}$ to the $4 \mathrm{M}, 6 \mathrm{M}$, and $8 \mathrm{M} \mathrm{HNO}_{3}$ solutions were discontinued before saturation was achieved. The amount of $\mathrm{Gd}\left(\mathrm{NO}_{3}\right)_{3}-6 \mathrm{H}_{2} \mathrm{O}$ added to each bottle is shown in Table 3-3. After additions were discontinued, the final solution volumes were measured for each bottle.

Table 3-3. Test Conditions for $\mathrm{HNO}_{3}$ - GdNH Solubility at $\mathbf{2 0 - 2 2}{ }^{\circ} \mathrm{C}$

\begin{tabular}{|c|c|c|c|}
\hline $\begin{array}{c}\mathrm{HNO}_{3} \\
(\mathrm{M})\end{array}$ & $\begin{array}{c}\text { Initial } \\
\text { Volume } \\
(\mathrm{mL})\end{array}$ & $\begin{array}{c}\text { GdNH } \\
\text { Added } \\
(\mathrm{g})\end{array}$ & $\begin{array}{c}\text { Final } \\
\text { Volume } \\
(\mathrm{mL})\end{array}$ \\
\hline 4 & 20.0 & $16.40^{*}$ & $26.1^{*}$ \\
\hline 6 & 20.0 & $16.13^{*}$ & $26.1^{*}$ \\
\hline 8 & 20.0 & $13.71^{*}$ & $25.0^{*}$ \\
\hline 10 & 20.0 & 12.49 & 24.8 \\
\hline \multicolumn{4}{|l}{} \\
\hline
\end{tabular}

The solutions prepared in $4 \mathrm{M}, 6 \mathrm{M}$, and $8 \mathrm{M} \mathrm{HNO}_{3}$ were uncapped, placed on a hot plate at $90{ }^{\circ} \mathrm{C}$ and gradually evaporated. The bottles were periodically removed from the hot plate, cooled to ambient temperature, and observed for the formation of a precipitate. If no precipitate was observed, the bottle was returned to the hot plate for further evaporation until precipitation occurred. The solutions were stored overnight at ambient temperature to confirm that saturation occurred. After all samples were saturated with GdNH, subsamples were collected from each solution for ICPES and total acid/free acid analyses. 


\subsection{Results and Discussion}

\subsection{Gadolinium Nitrate - Nitric Acid - Oxalic Acid}

Of the ten samples prepared, only seven precipitated (determined by visual observation) with the presence of precipitate in Sample 5 considered questionable. The supernatant liquids were analyzed for Gd concentration by ICPES. Those data are listed in Table 4-1. Based on the Gd data, the initial $\mathrm{H}_{2} \mathrm{C}_{2} \mathrm{O}_{4}$ concentration, and the stoichiometry for the formation of gadolinium oxalate $\left[\mathrm{Gd}_{2}\left(\mathrm{C}_{2} \mathrm{O}_{4}\right)_{3}\right]$, the soluble concentrations of $\mathrm{C}_{2} \mathrm{O}_{4}{ }^{2-}$ were calculated and are provided in Table 4-1. The soluble Gd and the calculated $\mathrm{C}_{2} \mathrm{O}_{4}{ }^{2-}$ concentrations for 4-8 $\mathrm{M} \mathrm{HNO}_{3}$ are graphed along with the 1927 data from Sarver and Brinton ${ }^{[1]}$ in Figure 4-1.

The $4 \mathrm{M} \mathrm{HNO}_{3}$ data for the current study exhibit good agreement with the data from the literature. The trend for the $6 \mathrm{M} \mathrm{HNO}_{3}$ samples appears to follow that of the 2-4 $\mathrm{M} \mathrm{HNO}_{3}$ samples. Consequently, the formation of precipitate in Sample 5 would be borderline because it is near the projected solubility limit. Similarly, precipitates in Samples 3, 7, and 9 would not be expected. Analyses of the oxalate concentrations (Table 4-1) agree with the calculated values within analytical uncertainty for all samples except Sample 10.

Table 4-1. Soluble Gadolinium and Oxalate Concentrations in 4-10 $\mathrm{M} \mathrm{HNO}_{3}$ at $25{ }^{\circ} \mathrm{C}$

\begin{tabular}{|c|c|c|c|c|c|c|}
\hline Sample & $\begin{array}{c}\mathrm{HNO}_{3} \\
(\mathrm{M})\end{array}$ & $\begin{array}{c}\mathrm{H}_{2} \mathrm{C}_{2} \mathrm{O}_{4} \\
(\mathrm{M})\end{array}$ & $\begin{array}{c}\mathrm{Gd} \\
(\mathrm{g} / \mathrm{L})\end{array}$ & $\begin{array}{c}\text { Days to } \\
\text { Precipitate }\end{array}$ & $\begin{array}{l}\text { Soluble Gd } \\
\text { (g/L)* }\end{array}$ & $\begin{array}{c}\text { Soluble } \mathrm{C}_{2} \mathrm{O}_{4}{ }^{2-}(\mathrm{M}) \\
\text { [Calc / Measure*] }\end{array}$ \\
\hline 1 & 4 & 0.15 & 8 & 4 & 3.47 & 0.107 / 0.109 \\
\hline 2 & 4 & 0.25 & 4 & 1 & 1.03 & 0.222 / NM \\
\hline 3 & 6 & 0.15 & 8 & $\mathrm{NP}>11$ & 8.05 & $0.150 / 0.151$ \\
\hline 4 & 6 & 0.25 & 8 & 4 & 7.18 & 0.242 / 0.232 \\
\hline 5 & 6 & 0.15 & 12 & 11 & 11.5 & 0.144 / 0.131 \\
\hline 6 & 6 & 0.25 & 12 & 4 & 7.86 & $0.211 / 0.207$ \\
\hline 7 & 8 & 0.15 & 12 & $\mathrm{NP}>11$ & 12.0 & 0.150 / NM \\
\hline 8 & 8 & 0.25 & 12 & 4 & 11.5 & 0.245 / NM \\
\hline 9 & 10 & 0.15 & 12 & $\mathrm{NP}>11$ & 11.9 & $0.150 / \mathrm{NM}$ \\
\hline 10 & 10 & 0.25 & 12 & 5 & 12.2 & $0.252 / 0.144$ \\
\hline \multicolumn{7}{|c|}{$\begin{array}{l}\text { * Measurement uncertainty for ICP } \\
\mathrm{NP}>11=\text { no precipitate after } 11 \mathrm{~d} \\
\mathrm{NM}=\text { not measured }\end{array}$} \\
\hline
\end{tabular}

For Sample 10, the Gd measurement of $12.2 \mathrm{~g} / \mathrm{L}$ does not agree with the observation that a precipitate formed after five days. If the measured value for $\mathrm{C}_{2} \mathrm{O}_{4}{ }^{2-}$ was used to calculate the corresponding Gd concentration, the calculated Gd concentration would be $1.0 \mathrm{~g} / \mathrm{L}$, which is also not consistent with the observed precipitation behavior. It is not known if the high $\mathrm{HNO}_{3}$ concentration is having a negative impact on the sample (i.e., decomposition of $\mathrm{H}_{2} \mathrm{C}_{2} \mathrm{O}_{4}$ ). 


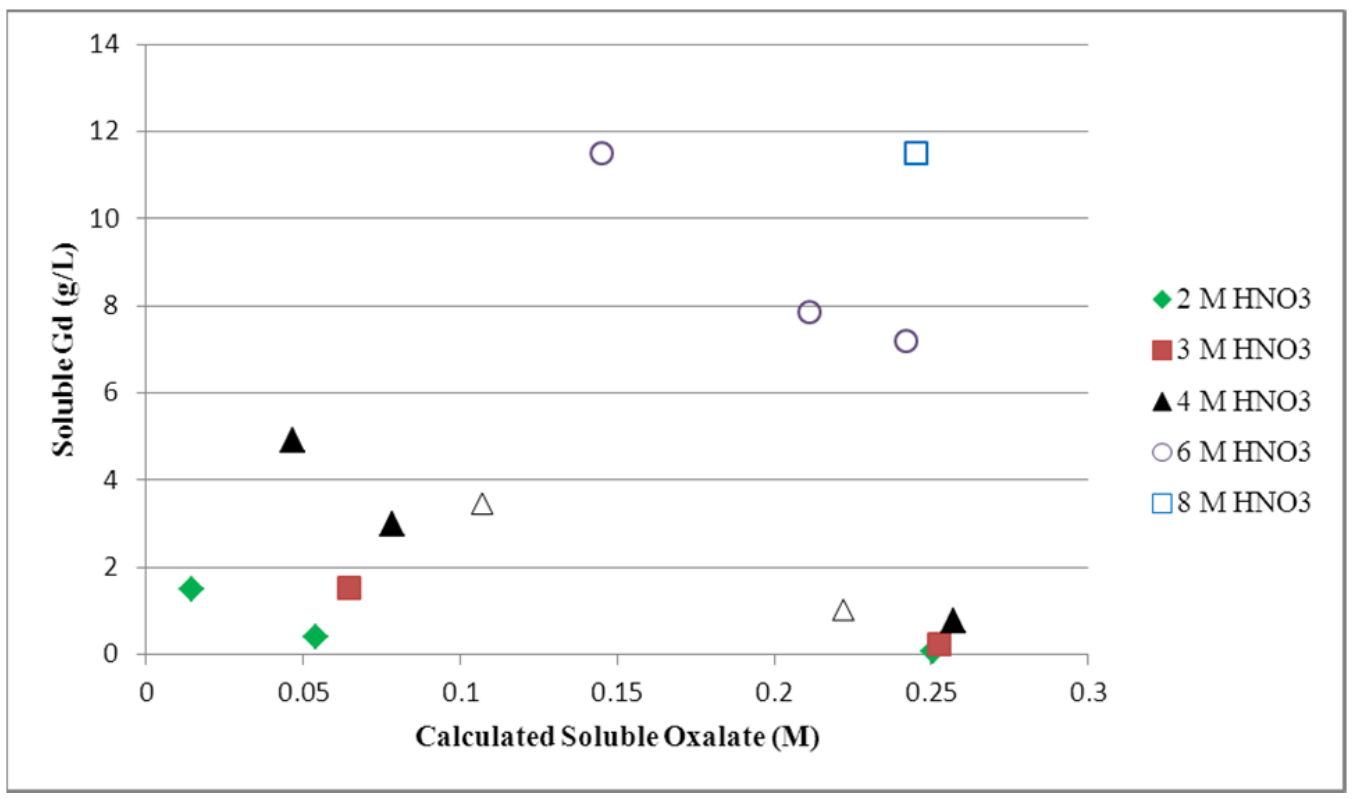

Figure 4-1. Gadolinium Solubility as Functions of $\mathrm{HNO}_{3}$ and $\mathrm{Oxalate}$ at $25{ }^{\circ} \mathrm{C}$

Interpolation of the $4 \mathrm{M} \mathrm{HNO}_{3}$ data in Figure 4-1 indicates that, for the system containing only $\mathrm{Gd}, \mathrm{H}_{2} \mathrm{C}_{2} \mathrm{O}_{4}$, and $\mathrm{HNO}_{3}, 2.5 \mathrm{~g} / \mathrm{L}$ and $0.8 \mathrm{~g} / \mathrm{L} \mathrm{Gd}$ are soluble in $0.15 \mathrm{M}$ and $0.25 \mathrm{M}$ oxalate, respectively. Similarly, at $6 \mathrm{M} \mathrm{HNO}_{3}, 11 \mathrm{~g} / \mathrm{L}$ and $7 \mathrm{~g} / \mathrm{L} \mathrm{Gd}$ are soluble in $0.15 \mathrm{M}$ and $0.25 \mathrm{M}$ oxalate, respectively. The increase in solubility from $4 \mathrm{M}$ to $6 \mathrm{M} \mathrm{HNO}_{3}$ was expected, but the magnitude of the increase was not anticipated. The solubility of $\mathrm{Gd}$ at 8-10 $\mathrm{M} \mathrm{HNO}_{3}$ is greater than the solubility at $6 \mathrm{M} \mathrm{HNO}_{3}$. It should be noted that the addition of other cations, such as iron, would create competition with Gd for oxalate and would thus likely increase Gd solubility. ${ }^{[6]}$ Plutonium(III) shows similar behavior to that of $\mathrm{Gd}$, but the data are too few to draw direct comparisons. ${ }^{[7]}$

The solubility data measured at $10{ }^{\circ} \mathrm{C}$ are listed in Table 4-2. The measured Gd data which exhibit a decrease in Gd for Samples 1 and 5 and not Sample 3 and 7 agree with the observed precipitation behavior. A comparison of the $10^{\circ} \mathrm{C}$ and $25{ }^{\circ} \mathrm{C}$ data is shown in Figure $4-2$. The $10{ }^{\circ} \mathrm{C}$ samples, as expected, have a lower solubility than the $25^{\circ} \mathrm{C}$ samples. The difference in solubility is outside of the method uncertainty of $10 \%$. Based on Figure 4-2, the solubility of Gd at $4 \mathrm{M} \mathrm{HNO}_{3}$ with $0.15 \mathrm{M}$ oxalate at $10{ }^{\circ} \mathrm{C}$ is about $1.5 \mathrm{~g} / \mathrm{L}$. Similarly, in $6 \mathrm{M} \mathrm{HNO}_{3}$, the solubility of $\mathrm{Gd}$ with $0.15 \mathrm{M}$ oxalate at $10^{\circ} \mathrm{C}$ is about $10 \mathrm{~g} / \mathrm{L}$.

Table 4-2. Soluble Gadolinium and Oxalate Concentrations in 4-8 $\mathrm{M} \mathrm{HNO}_{3}$ at $10{ }^{\circ} \mathrm{C}$

\begin{tabular}{|c|c|c|c|c|c|c|}
\hline Sample & $\begin{array}{c}\mathrm{HNO}_{3} \\
(\mathrm{M}) \\
\end{array}$ & $\begin{array}{c}\mathrm{H}_{2} \mathrm{C}_{2} \mathrm{O}_{4} \\
(\mathrm{M})\end{array}$ & $\begin{array}{c}\mathrm{Gd} \\
(\mathrm{g} / \mathrm{L})\end{array}$ & $\begin{array}{c}\text { Days to } \\
\text { Precipitate } \\
\end{array}$ & $\begin{array}{c}\text { Soluble Gd } \\
(\mathrm{g} / \mathrm{L})^{*}\end{array}$ & $\begin{array}{c}\text { Soluble } \mathrm{C}_{2} \mathrm{O}_{4}{ }^{2-}(\mathrm{M})^{*} \\
{[\text { Calc / Measure }]}\end{array}$ \\
\hline 1 & 4 & 0.157 & 8.76 & 1 & 2.02 & $0.093 / 0.102$ \\
\hline 3 & 6 & 0.150 & 8.00 & $\mathrm{NP}>4$ & 7.97 & $0.150 / 0.156$ \\
\hline 5 & 6 & 0.151 & 12.1 & 1 & 10.6 & 0.137 / 0.137 \\
\hline 7 & 8 & 0.150 & 12.0 & $\mathrm{NP}>4$ & 12.2 & 0.152 / 0.145 \\
\hline
\end{tabular}




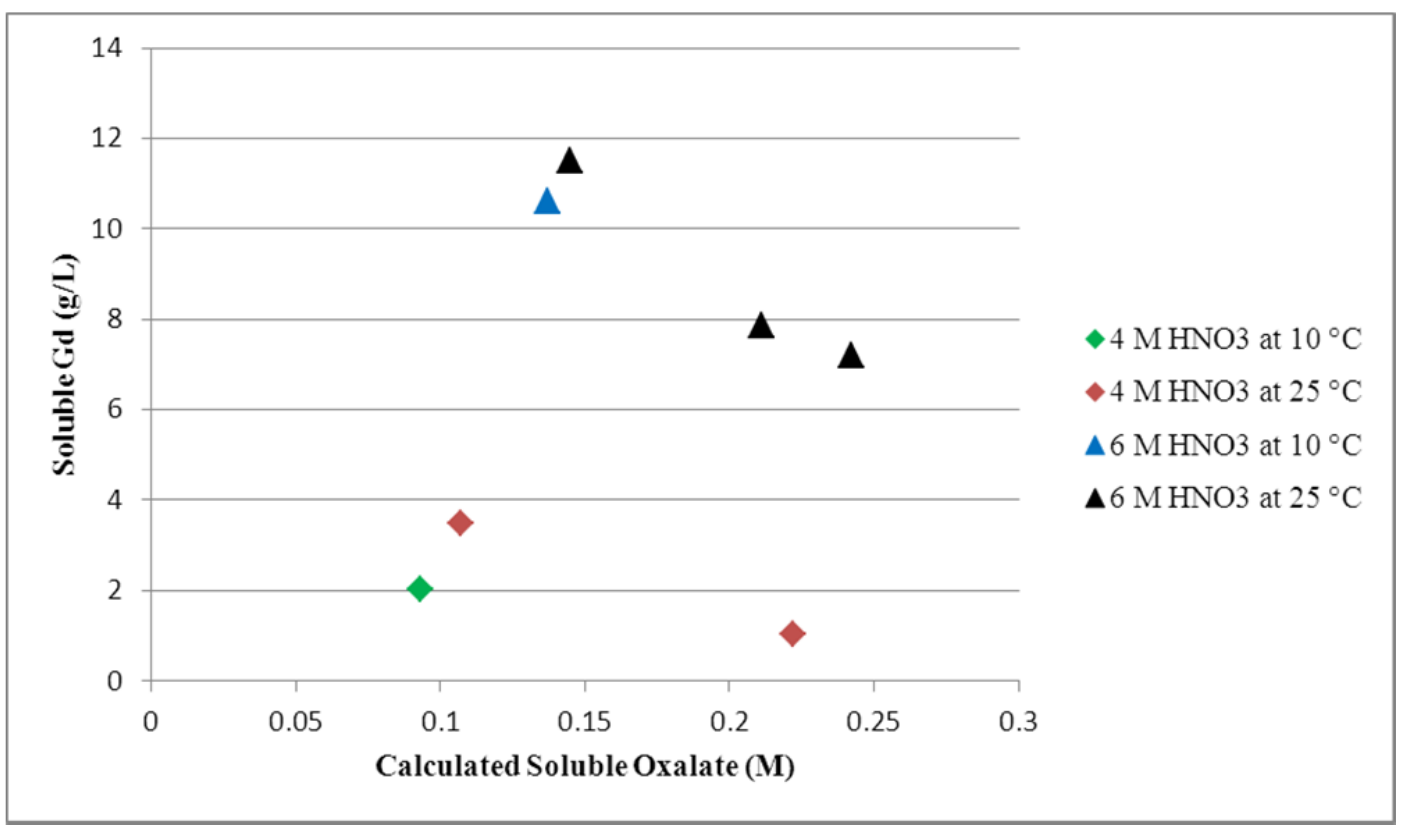

Figure 4-2. Gadolinium Solubility as Functions of $\mathrm{HNO}_{3}$ and Oxalate at 10 and $25{ }^{\circ} \mathrm{C}$

\subsection{Gadolinium Nitrate - Nitric Acid}

After the addition of GdNH to the four solution concentrations, only one sample (10 $\left.\mathrm{M} \mathrm{HNO}_{3}\right)$ contained undissolved $\mathrm{GdNH}$, indicating it was saturated. Based on the initial volume, final volume, and mass of $\mathrm{GdNH}$ added, the final $\mathrm{Gd}$ and $\mathrm{HNO}_{3}$ concentrations for each sample were calculated. The calculated values are provided in Table 4-3.

Table 4-3. Calculated Solution Concentrations after Addition of GdNH

\begin{tabular}{|c|c|c|c|c|c|}
\hline $\begin{array}{c}\mathrm{HNO}_{3} \\
(\mathrm{M})\end{array}$ & $\begin{array}{c}\text { Initial } \\
\text { Volume } \\
(\mathrm{mL})\end{array}$ & $\begin{array}{c}\text { GdNH } \\
\text { Added } \\
(\mathrm{g})\end{array}$ & $\begin{array}{c}\text { Final } \\
\text { Volume } \\
(\mathrm{mL})\end{array}$ & $\begin{array}{c}\text { Final } \\
\mathrm{Gd} \\
(\mathrm{g} / \mathrm{L})\end{array}$ & $\begin{array}{c}\text { Final } \\
\mathrm{HNO}_{3} \\
(\mathrm{M})\end{array}$ \\
\hline 4 & 20.0 & 16.40 & 26.1 & 219 & 3.1 \\
\hline 6 & 20.0 & 16.13 & 26.1 & 215 & 4.6 \\
\hline 8 & 20.0 & 13.71 & 25.0 & 191 & 6.4 \\
\hline 10 & 20.0 & 12.49 & 24.8 & $<175^{*}$ & 8.1 \\
\hline
\end{tabular}

After the $4 \mathrm{M}, 6 \mathrm{M}$, and $8 \mathrm{M} \mathrm{HNO}_{3}$ solutions were evaporated to saturation, all samples were analyzed for $\mathrm{Gd}$ and $\mathrm{HNO}_{3}$ concentrations. Those data are shown in Table 4-4. The uncertainty for the $\mathrm{Gd}$ and $\mathrm{HNO}_{3}$ data is $10 \%$. The total acid and Gd data are plotted in Figure 4-3. The solubility of Gd appears to be linear as a function of $\mathrm{HNO}_{3}$ from $343 \mathrm{~g} / \mathrm{L} \mathrm{Gd}$ in $2.88 \mathrm{M} \mathrm{HNO}_{3}$ to $149 \mathrm{~g} / \mathrm{L}$ in $8.16 \mathrm{M} \mathrm{HNO}_{3}$; Gd solubility appears to approach a limit below $2.88 \mathrm{M} \mathrm{HNO}_{3}$, although there are no data below $1.40 \mathrm{M} \mathrm{HNO}_{3}$. The behavior above $8.16 \mathrm{M}$ is not known. 
Table 4-4. Solubility Data for $\mathrm{GdNH}$ in $\mathrm{HNO}_{3}$ at $20-22{ }^{\circ} \mathrm{C}$

\begin{tabular}{|c|c|c|c|}
\hline $\begin{array}{c}\text { Initial } \mathrm{HNO}_{3} \\
(\mathrm{M})\end{array}$ & $\begin{array}{c}\text { Free } \mathrm{H}^{+} \\
(\mathrm{M})\end{array}$ & $\begin{array}{c}\text { Total } \mathrm{H}^{+} \\
(\mathrm{M})\end{array}$ & $\begin{array}{c}\text { Gd at } \\
\text { Saturation } \\
(\mathrm{g} / \mathrm{L})\end{array}$ \\
\hline 4 & 1.08 & 1.40 & 353 \\
\hline 6 & 1.91 & 2.88 & 343 \\
\hline 8 & 4.74 & 4.84 & 252 \\
\hline 10 & 7.72 & 8.16 & 149 \\
\hline \multicolumn{4}{|r}{} \\
\hline \multicolumn{4}{|c}{} \\
\hline
\end{tabular}

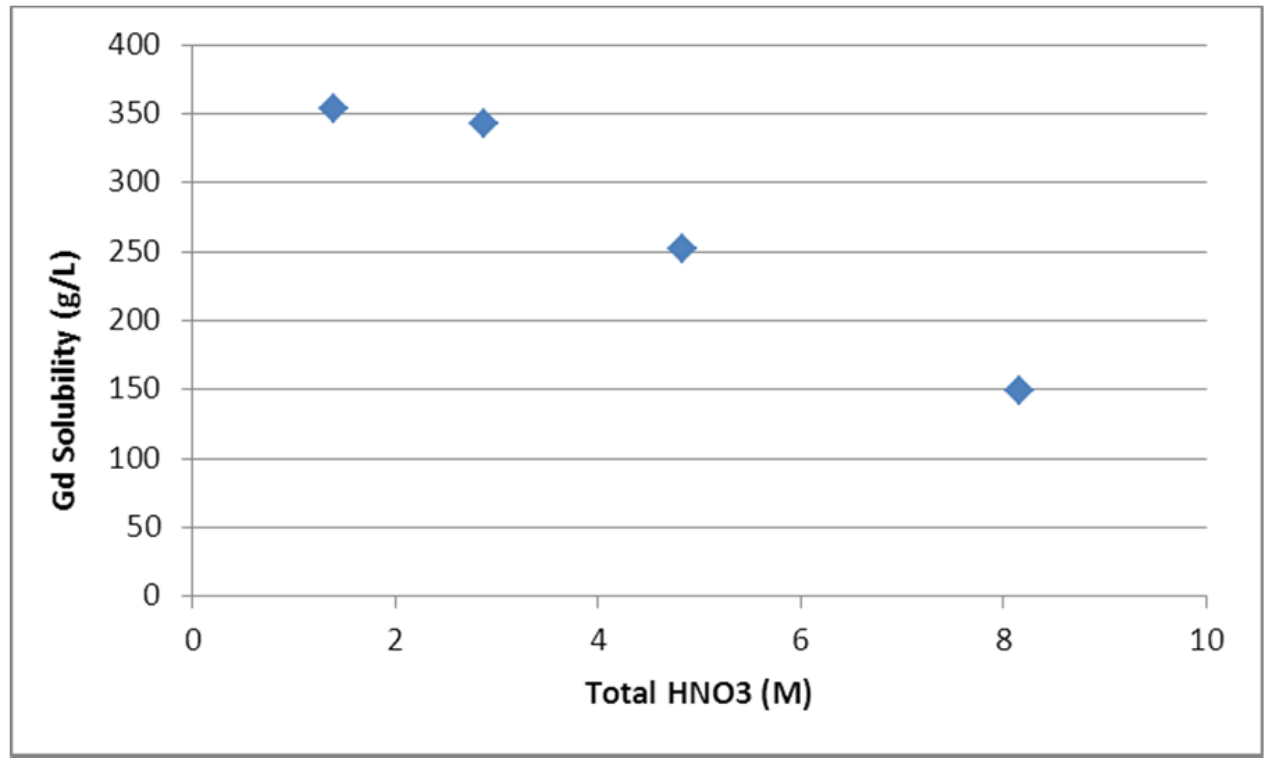

Figure 4-3. GdNH Solubility as Functions of $\mathrm{HNO}_{3}$ at $20-22{ }^{\circ} \mathrm{C}$

\subsection{Conclusions}

SRNL measured gadolinium oxalate solubility at 4-10 $\mathrm{M} \mathrm{HNO}_{3}, 4-12 \mathrm{~g} / \mathrm{L} \mathrm{Gd}$, and 0.15-0.25 M oxalate at $10{ }^{\circ} \mathrm{C}$ and $25^{\circ} \mathrm{C}$. At $25^{\circ} \mathrm{C}$, solubility data for $4 \mathrm{M} \mathrm{HNO}_{3}$ show good agreement with data in the literature. The data indicate that the target of $6 \mathrm{~g} / \mathrm{L}$ soluble $\mathrm{Gd}$ can be achieved above $6 \mathrm{M} \mathrm{HNO}_{3}$ and below $0.25 \mathrm{M} \mathrm{H}_{2} \mathrm{C}_{2} \mathrm{O}_{4}$. For $0.15 \mathrm{M}$ oxalate, $2.5 \mathrm{~g} / \mathrm{L}$ and $11 \mathrm{~g} / \mathrm{L} \mathrm{Gd}$ are soluble in $4 \mathrm{M}$ and $6 \mathrm{M} \mathrm{HNO}_{3}$, respectively. For $0.25 \mathrm{M}$ oxalate, $0.8 \mathrm{~g} / \mathrm{L}$ and $7 \mathrm{~g} / \mathrm{L} \mathrm{Gd}$ are soluble in $4 \mathrm{M}$ and $6 \mathrm{M} \mathrm{HNO}_{3}$, respectively. The increase in Gd solubility from $4 \mathrm{M}$ to $6 \mathrm{M} \mathrm{HNO}_{3}$ was expected, but the magnitude of the increase in solubility was greater than expected. The solubility of Gd at 8-10 $\mathrm{M} \mathrm{HNO}_{3}$ exceeds the solubility at $6 \mathrm{M} \mathrm{HNO}_{3}$.

The solubility of $\mathrm{Gd}$ in $4 \mathrm{M} \mathrm{HNO}_{3}$ and $0.15 \mathrm{M}$ oxalate at $10{ }^{\circ} \mathrm{C}$ is about $1.5 \mathrm{~g} / \mathrm{L}$. For $6 \mathrm{M} \mathrm{HNO}_{3}$ and $0.15 \mathrm{M}$ oxalate, the solubility of $\mathrm{Gd}$ at $10^{\circ} \mathrm{C}$ is about $10 \mathrm{~g} / \mathrm{L}$.

Gadolinium nitrate is very soluble in $\mathrm{HNO}_{3}$. The solubility of $\mathrm{Gd}$ exhibits linearity as a function of $\mathrm{HNO}_{3}$ from $343 \mathrm{~g} / \mathrm{L}$ Gd in $2.88 \mathrm{M} \mathrm{HNO}_{3}$ to $149 \mathrm{~g} / \mathrm{L}$ in $8.16 \mathrm{M} \mathrm{HNO}_{3}$. Below $2.88 \mathrm{M} \mathrm{HNO}_{3}$, the solubility of Gd approaches a limit of about $360 \mathrm{~g} / \mathrm{L}$, although no data exist below $1.40 \mathrm{M}$ $\mathrm{HNO}_{3}$. 


\subsection{References}

1. L. A. Sarver and P. H. Brinton, "The Solubilities of Some Rare-Earth Oxalates”, J. Am. Chem. Soc., 1927, 49, 943-958.

2. W. G. Dyer, "Gadolinium Solubility Study for AFS-2 Filtrate Receipt by H-Canyon," Technical Task Request NMMD-HTS-2012-3194 (January 30, 2012).

3. W. G. Dyer, "Additional Gadolinium Solubility Study for AFS-2 Filtrate Receipt by H-Canyon,” Technical Task Request NMMD-HTS-2012-3199 (February 27, 2012).

4. R. A. Pierce, "Recovery of Curium-Americium as an Oxalate Using a Precipitation-Settling Concept,” WSRC-RP-94-0392 (1994).

5. C. E. Crouthamel and D. S. Martin, Jr., "Solubility of the Rare Earth Oxalates and Complex Ion Formation in Oxalate Solution, II,” J. Am. Chem. Soc., 1951, 73, 569-573.

6. C. A. Nash, "Literature Review for Oxalate Oxidation Processes and Plutonium Oxalate Solubility”, SRNL-STI-2012-0003 (January 2012).

7. O. J. Wick (ed), Plutonium Handbook, A Guide to the Technology, American Nuclear Society, 317 (1980). 


\section{Distribution:}
A.B. Barnes, 999-W
S.D. Fink, 773-A
B.J. Giddings, 786-5A
C.C. Herman, 999-W
S.L. Marra, 773-A
F.M. Pennebaker, 773-42A
W.E. Harris, 704-2H
J.B. Schaade, 704-2H
G.J. Zachman, 225-7H
P.B. Andrews, 704-2H
S.J. Howell, 704-2H
K.A. Dukes, 221-H
M.J. Lewczyk, 221-H
K.J. Gallahue, 221-H
K.D. Scaggs, 704-2H
K.P. Burrows, 704-2H
S.L. Garrison, 704-2H
W.H. Clifton, 704-2H
J.W. Christopher, 704-2H
W. G. Dyer, 704-2H
E.A. Kyser, 773-A
N.J. Bridges, 773-A
C.A. Nash, 773-42A
R.A. Pierce, 773-A
S.A. Thomas, 703-46A 